\title{
ANALISIS PERSEPSI TINGKAT KEPUASAN MASYARAKAT TERHADAP KINERJA PELAYANAN RUMAH SAKIT UMUM RADEN MATTAHER JAMBI
}

\author{
Oleh \\ Etik Winarni ${ }^{1}$ \\ Dosen Tetap Universitas Muhammadiyah Jambi ${ }^{\mathbf{1}}$ \\ Etikwinarni88@gmail.com \\ Iwan Eka Putra ${ }^{2}$ \\ Dosen Tetap Universitas Muhammadiyah Jambi² \\ Iwanej@yahoo.com \\ Mutia Wita Prasetia ${ }^{3}$ \\ Mahasiswa Universitas Muhammadiyah Jambi ${ }^{3}$
}

\begin{abstract}
Ringkasan
Pelayanan publik ini merupakan sebuah perusahan jasa seperti rumah sakit harus menjaga kualitas jasa yang ditawarkan karena bila kualitas jasa yang didapatkan oleh konsumen melebihi harapannya maka akan terbentuk suatu loyalitas konsumen terhadap rumah sakit tersebut begitupun sebaliknya. Berdasarakan latar belakang diatas maka peneliti tertarik untuk menganalisa lebih jauh tentang “Analisis Persepsi Tingkat Kepuasan Masyarakat Terhadap Kinerja Pelayanan Rumah Sakit Umum Raden Mattaher Jambi”. Data yang dianalisis menggunakan Uji validitas dan reliabilitas untuk data kuesioner dan importance performance Analysis (IPA). Dari hasil analisis dan pembahasan penelitian Kualitas pelayanan terletak pada Kuadran I dilaksanakannya pelayanan oleh Perawat segera menghubungi dokter mengenai obat dan makanan Pasien serta perawat memastikan keluhan keluarga pasien dianggap penting tetatpi kenyataannya kinerjanya belum sesuai seperti yang diharpakan yang dinilai responden memiliki arti penting dan kinerja rendah dalam menjaga kualitas pelayanan rumah sakit. Faktor-faktor yang terletak pada kuadran 2 ini dinilai responden memiliki arti penting dan kinerja sangat tinggi dalam menjaga kualitas pelayanan rumah sakit. Variabel yang terletak pada kuadran III dinilai oleh responden memiliki arti penting yang sangat tinggi tetapi memiliki hasil kinerja sangat rendah, yang artinya setiap hasil responden dalam tiap variabel-variabel tersebut memiliki hasil kinerja sangat rendah. Dengan demikian pihak pengelola perlu memberikan perhatian terhadap faktor-faktor tesebut sehingga dalam keberadaan Tangibility, Reliability, Responsiveness, Assurance, Empaty untuk dapat ditingkatkan kinerjanya sesuai dengan perkembangan kebutuhan masing-masing pihak dengan tujuan kualitas pelayanan rumah sakit. Kualitas pelayanan terletak pada Kuadran IV dilaksanakannya pelayanan oleh Perawat melaporkan segala detail perubahan pasien kepada dokter sewaktu melakukan kunjungan Penilaian kondisi pelayanan kinerjanya cukup baik namun dipandang cenderung berlebihan.
\end{abstract}

Kata kunci : validitas, reliabilitas, importance performance Analysis (IPA) 


\section{PENDAHULUAN}

Dalam pelayanan publik dibidang Kesehatan yang saat ini sudah menjadi kebutuhan pokok dari tiap manusia. Tidak hanya di negara maju yang menjadikan kesehatan sebagai prioritas utama bagi masyarakat, begitu juga pada negara yang berkembang seperti Indonesia. Masalah kesehatan menjadi hal penting yang dipertimbangkan karena kualitas hidup atau harapan hidup masyarakat pada suatu Negara menjadi alat ukur kesejahteraan masyarakatnya. Dalam memenuhi kebutuhan untuk pelayanan kesehatan bagi masyarakat, pemerintah sudah menyediakan fasilitas kesehatan diantaranya Puskesmas dan RSUD maupun RSU milik Swasta. Pelayanan kesehatan menjadi kebutuhan vital bagi masyarakat dengan banyaknya masyarakat yang membutuhkan pelayanan kesehatan maka pemerintah banyak melakukan program kesehatan dengan harga terjangkau.

Pelayanan rumah sakit sebagai penyedia layanan jasa kesehatan harusnya memperhatikan kebutuhan dan kepuasan pasien pengguna layanan kesehatan. Pelayanan merupakan kegiatan interaksi langsung antara seseorang dengan orang lain dan menyediakan kepuasan pelanggan. Kualitas layanan merupakan isu yang sangat penting bagi setiap perusahaan apapun bentuk produk yang dihasilkan. Pelayanan publik ini merupakan sebuah perusahan jasa seperti rumah sakit harus menjaga kualitas jasa yang ditawarkan karena bila kualitas jasa yang didapatkan oleh konsumen melebihi harapannya maka akan terbentuk suatu loyalitas konsumen terhadap rumah sakit tersebut begitupun sebaliknya. Berdasarakan latar belakang diatas maka peneliti tertarik untuk menganalisa lebih jauh tentang bagaimana faktor-faktor yang mempengaruhi tingkat kepuasan terhadap kinerja pelayanan Rumah Sakit Umum Raden Mattaher Jambi?

\section{METODOLOGI}

\section{Skala Likert}

Data primer yang diperoleh melalui kuesioner diukur dengan menggunakan skala likert. Setiap jawaban atas butir pertanyaan berbentuk pilihan dengan beberapa alternative pilihan jawaban yang memiliki scoring tertentu. Skala likert adalah skala yang digunakan untuk mengkuantitatifkan persepsi kualitatif responden atas setiap pertanyaan atau skala yang digunakan untuk mengukur sikap, pendapat seseorang/sekelompok orang tentang fenomena social. Jawaban setiap butir instrument yang menggunakan skala likert mempunyai gradasi dari sangat positif sampai negative. Untuk keperluan analisis kuantitatif, jawaban tersebut di beri skor: 
1. Sangat Tidak Baik ( STB ) Diberi skor 1;

2. Tidak Baik ( TB ) Diberi skor 2;

3. Kurang Baik ( KB ) Diberi skor 3;

4. Baik ( B ) Diberi skor 4;

5. Sangat Baik ( SB ) Diberi skor 5.

Pengisian kuesioner responden dalam penelitian ini diminta untuk menilai seberapa penting faktor-faktor yang mempengaruhi kualitas pelayanan terhadap tingkat kepuasan masyarakat. Responden terlibat langsung dalam faktor-faktor yang mempengaruhi kualitas pelayanan terhadap tingkat kepuasan masyarakat diukur dengan skala likert dari 1 sampai 5 Jawaban gradasi dari sangat positif sampai sangat negative, yang dapat berupa kata-kata, item instrument yang digunakan untuk tingkat kepentingan (importance) dan kinerja (performance) adalah sebagai berikut.

Tabel .1

Bobot skor Importance-Performance

\begin{tabular}{|l|c|c|l|c|}
\hline $\begin{array}{c}\text { Importance } \\
\text { (Tingkat Kepentingan) } \\
\text { Uraian Item }\end{array}$ & $\begin{array}{c}\text { Bobot } \\
\text { Skor }\end{array}$ & \multicolumn{2}{c|}{$\begin{array}{c}\text { Performance } \\
\text { Tingkat Kinerja) } \\
\text { Uraian Item }\end{array}$} \\
\hline Sangat Tidak Baik & $(\mathrm{STB})$ & 5 & Sangat Tidak Baik & (STB) \\
\hline Tidak Baik & $(\mathrm{TB})$ & 4 & Tidak Baik & $(\mathrm{TB})$ \\
\hline Kurang Baik & $(\mathrm{KB})$ & 3 & Kurang Baik & $(\mathrm{KB})$ \\
\hline Baik & $(\mathrm{B})$ & 2 & Baik & $(\mathrm{B})$ \\
\hline Sangat Baik & (SB) & 1 & Sangat Baik & (SB) \\
\hline
\end{tabular}

Sumber: Lampiran 2 diolah

Analisis data yang diperoleh melalui kuesioner bertujuan untuk mengetahui arti penting dan tingkat pelayanan dirumah sakit umum provinsi jambi. Kuesioner tersebut dianalisis dengan menggunakan skala likert. Skala Likert digunakan untuk mengukur respon subjek ke dalam lima poin atau tujuh poin skala dengan interval yang sama (Jogiyanto,2011: 184). Dalam pengisian kuesioner ini para responden menilai seberapa penting faktor-faktor penentu keberhasilan manajemen asset kualitas pelayanan terhadap tingkat kepuasan masyarakat dan seberapa baik pelaksanaan faktor-faktor keberhasilan tersebut.

Kepentingan dan kinerja diukur dengan skala Likert dengan interval dari 1 sampai 5 jawaban setiap item instrument yang menggunakan skala Likert mempunyai gradasi dari sangat positif sampai sangat negatif, yang dapat berupa kata-kata. Jumlah skor ideal (tertinggi) untuk seluruh item adalah 5 (lima) dikalikan jumlah responden sangat tinggi, sedangkan skor 
terendah adalah 1 (satu) dikalikan jumlah responden sangat rendah. Jumlah skor tertinggi (ideal) untuk seluruh item adalah 5 x 50 responden $=250(\mathrm{SP} / \mathrm{SB})$, Sedangkan skor terendah adalah 1 x 50 responden $=50(\mathrm{TP} / \mathrm{TB})$.

Teknik perhitungan sebagai berikut:

1. jumlah responden yang memilih suatu item dikalikan skor item yang dipilih;

2. hasil perkalian dijumlahkan;

3. hasil penjumlahan tersebut yang menentukan item.

\begin{tabular}{l|l|l|l|l|}
0 & \multicolumn{2}{|c}{50} & 100 & \multicolumn{2}{c}{200} & 250 \\
\hline $\begin{array}{l}\text { Tidak penting/ } \\
\text { /tidak Baik }\end{array}$ & $\begin{array}{l}\text { Kurang } \\
\text { penting/baik }\end{array}$ & $\begin{array}{l}\text { cukup penting/ } \\
\text { cukup baik }\end{array}$ & $\begin{array}{l}\text { penting/ } \\
\text { baik }\end{array}$ & $\begin{array}{l}\text { sangat penting/ } \\
\text { sangat baik }\end{array}$
\end{tabular}

Semakin tinggi hasil penjumlahan menunjukan bahwa faktor-faktor penentu keberhasilan semakin penting dan kinerja manjemen asset semakin baik. Rumus untuk memperoleh presentase tingkat kepentingan dan kinerja berdasarkan item-item pertanyaan-pertanyaan faktor-faktor penentu keberhasilan adalah sebagai berikut:

Tingkat persepsi responden $=$ skor yang diperoleh $\mathrm{X} 100 \%$

\section{Skor tertinggi}

Dari jumlah skor, berdasarkan karakteristik data primer yang diperoleh dapat menentukan skala sebagai berikut ( sugiono,2011: 138).

\begin{tabular}{|c|c|c|c|c|}
\hline $0 \%$ & & $40 \%$ & $60 \%$ & 10 \\
\hline Sangat rendah & rendah & sedang & tinggi & sangat tinggi \\
\hline
\end{tabular}

Keterangan kriteria interprestasi skor: angka 0 persen-20 persen $=$ sangat rendah; angka 21 persen-40 persen = rendah; angka 41 persen- 60 persen $=$ sedang; angka 61 persen- 80 persen $=$ tinggi, angka 81 persen-100 persen = sangat tinggi.

\subsubsection{Uji validitas dan reliabilitas}

Uji validitas dan reliabilitas merupakan proses pengujian butir-butir pertanyaan yang ada dalam kuesioner, apakah isi dari butir-butir pertanyaan tersebut sudah valid dan reliabel. Valid artinya jika pertanyaan pada suatu angket mampu untuk mengungkapkan sesuatu yang akan diukur, sedangkan reliabel artinya jawaban responden terhadap pertanyaan adalah konsisten atau stabil dari waktu ke waktu (Santoso, 2002; 270). 


\subsubsection{Uji validitas}

Uji validitas dilakukan untuk mengetahui tingkat kemampuan instrument penelitian tersebut dalam mengungkapkan data apakah sesuai dengan masalah yang hendak diungkapkan. Dengan kata lain, validitas menunjukan sejauh mana suatu alat ukur itu mengukur apa yang ingin diukur. Untuk mengetahui validitas instrument dalam penelitian ini digunakan korelasi pearson product moment yang di rumuskan sebagai berikut (sunarto, dkk., 2005: 20).

$$
\text { R hitung }=\frac{\mathrm{N}\left(\Sigma^{\mathrm{XY}}\right)-\left(\Sigma^{\mathrm{X}} \Sigma^{\mathrm{Y}}\right)}{\sqrt{\left(\mathrm{N} \Sigma \mathrm{X}^{2}-(\Sigma \mathrm{X})^{2}\right)\left(\mathrm{N} \Sigma \mathrm{Y}^{2}\right)(\Sigma \mathrm{Y})^{2}}}
$$

Di mana :

$\mathrm{R}_{\text {hitung }} \quad$ : koefisien korelasi product moment

$\mathrm{N} \quad$ : Jumlah responden

$\mathrm{X}$ dan $\mathrm{Y} \quad$ : skor masing-masing variabel

Alat bantu program software SPSS dapat digunakan untuk menentukan valid tidaknya suatu variabel yang diuji. Secara statistic hasil korelasi dibandingkan dengan angka kritis table korelasi dengan taraf signifikan 5 persen.

Jika angka korelasi hasil perhitungan lebih besar dari angka kritis, butir pertanyaan tersebut dinyatakan valid. Sebaliknya, jika angka korelasi hasil perhitungan lebih kecil daripada angka kritis, butir pertanyaan tersebut tida valid.

\subsubsection{Uji reliabilitas}

Uji reliabilitas dilakukan untuk mengetahui konsistensi responden dari waktu ke waktu dalam menjawab pertanyaan dalam kuesioner. Bila suatu alat pengukur dipakai dua kali untuk mengukur gejala yang sama dan hasil pengukuran yang di peroleh relative konsisten, alat pengukur tersebut dikatakan reliabel.

Reliabilitas Dihitung dengan menggunakan koefisien suatu alat bantu program software SPSS. Cronbach alpha sebagai interkorelasi rata-rata diantara item-item pengukuran, rumusan sebagai berikut:

$$
\begin{gathered}
\mathrm{a}=\{\mathrm{K}\}\left\{1-\Sigma \mathrm{Sj}^{2}\right\} \\
\mathrm{K}-1 \quad \mathrm{Sx}^{2}
\end{gathered}
$$

Di mana :

a $\quad=$ koefisien reliabilitas/instrument

$\mathrm{K}=$ banyaknya butir instrument

$\Sigma \mathrm{Sj}^{2} \quad=$ variasi $\mathrm{j}$ atau varian dari tiap butir $(\mathrm{j}=1,2, \ldots)$

$\mathrm{Sx}^{2} \quad=$ variasi skor tes atau varian table. 
Menurut Ghozali (2006), semakin mendekati 1 angka koefisien Cronbach alpha, semakin tinggi konsistensi relibilitas suatu alat ukur. Menurut Nunally (1967) suatu kontruk atau variabel dikatakan reliable jika nilai Cronbach alpa $>0,6$ (lihat kharir, 2009: 46).

\subsubsection{Importance-Performance analysis}

Importance-Performance analysis (IPA) merupakan teknik analisis yang pertama kali diperkenalkan oleh Martilla and James (1977) dalam studi pemasaran yang mereka lakukan. Mereka membagi tiga atribut kualitas produk ke dalam kerangka dua dimensional untuk menjelaskan hubungan antara derat kepuasan ( performance) dan derajat perhatian ( importance ) dari pelanggan sehingga ditemukannya gap yang dapat dievaluasi untuk penyempurnaan kualitas produk atau jasa. Dalam bidang manajemen asset, Schaeffer (1999) memakainya untuk menilai status progresivitas penerapan corporate real astate asset management pada perusahaan di jerman.

Dalam penelitian ini, atribut yang dipakai adalah pengaruh kualitas pelayanan terhadap tingkat kepuasan masyarakat di rumah sakit umum provinsi jambi. Analisis yang dilakukan dengan tahapan.

1. Membuat daftar faktor-faktor yang mempengaruhi kualitas pelayanan terhadap tingkat kepuasan masyarakat di rumah sakit umum provinsi jambi dan merumuskan kuesioner berdasarkan pengaruh kualitas pelayanan tersebut dengan alternatife jawaban menggunakan skala likert.

2. Memberikan skor terhadap tiap-tiap faktor-foktor yang mempengaruhi kualitas pelayanan yang diasosiasikan dengan persepsi "arti penting (importance)" dan "kinerja (performance)" untuk tiap faktor. Indikator importance mencerminkan derajat arti penting faktor tersebut. Indikator Performance mencerminkan seberapa besar derajat pelaksanaannya faktor-faktor tersebut dalam pengaruh kualitas pelayanan terhaddap tingkat kepuasan.

3. Meletakkan skor dalam diagram dua dimensi dengan performance sebagai sumbu $\mathrm{X}$ dan Importance sebagai sumbu Y.

4. Membagi keseluruhan diagram dalam empat sel dengan menggunakan skor rata-rata arti penting dan kinerja kualitas pelayanan terhadap tingkat kepuasan. Diagram importance dan performance analisis dapat dilihat pada Gambar 1.2 berikut. 


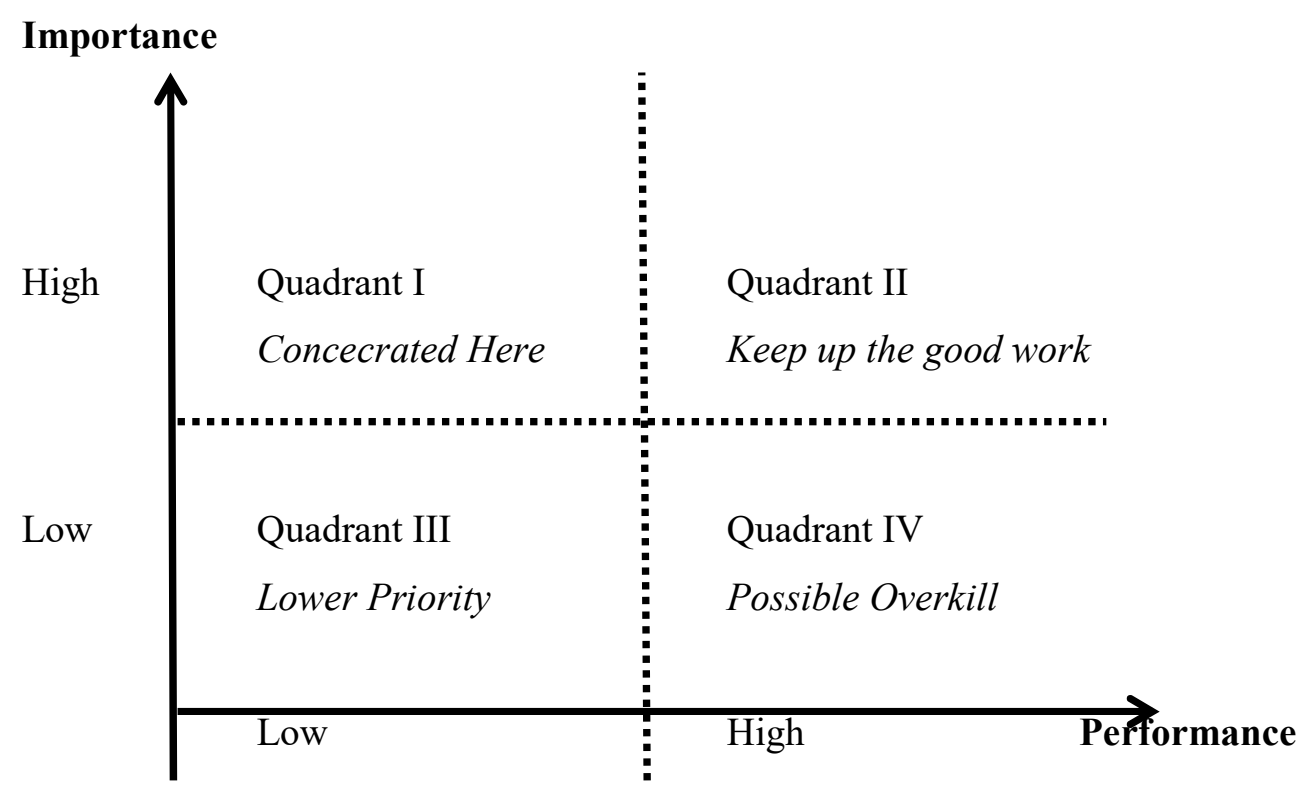

Sumber : Martilla dan James (1977)

\section{Gambar : 2.4 Diagram Importance-Performance Analysis}

a. Pada kuadran I yang dikonotasikan A (concentrate here/konsentrasi disini). Ini adalah wilayah yang memuat faktor-faktor yang mempengaruhi kualitas pelayanan terhadap tingkat kepuasan masyarakat dianggap penting, tetapi pada kenyataannya pelayanan belum sesuai seperti yang diharapkan. Variabel-variabel yang masuk dalam kuadran ini harus ditingkatkan tindakan konstruktif yang terkonsentrasi pada faktor-faktor tersebut dapat membuahkan hasil yang maksimal.

b. Pada kuadran II yang dikonotasikan B (Keep up the good work/pertahankan prestasi) ini adalah wilayah yang memuat faktor-faktor yang mempengaruhi kualitas pelayanan terhadap tingkat kepuasan masyarakat dianggap penting dan pelayanannya sesuai seperti yang diharapkan/cukup baik. Variabel-varibel yang masuk dalam kaudran ini harus dipertahankan.

c. Pada kuadran III yang dikonotasikan C (Low Priority/Prioritas rendah). Ini adalah wilayah yang memuat faktor-faktor yang mempengaruhi kualitas pelayanan terhadap tingkat kepuasan masyarakat kurang penting dan pelayanannya kurang baik. Manajemen tidak perlu memprioritaskan atau terlalu memberikan perhatian pada faktor-faktor yang ada di kuadran ini.

d. Pada kuadran IV yang dikonotasikan D (Possible Overkill/terlalu berlebih). Ini adalah wilayah yang memuat faktor-faktor yang mempengaruhi kualitas pelayanan terhadap 
tingkat kepuasan masyarakat yang pelayanannya cukup baik namun dipandang kurang penting atau dapat dikatakan berlebihan. Jika diperlukan, manajemen biasa mengalokasikan sumberdaya yang terkait dengan faktor-faktor yang ada di kuadran ini untuk kepada faktor-faktor lain yang mempunyai prioritas penanganan lebih tinggi tetap melaksanakan atau memperaktikan faktor-faktor keberhasilan yang mempengaruhi kualitas pelayanan terhadap tingkat kepuasan masyarakat yang ada di kuadran ini.

\section{HASIL DAN PEMBAHASAN}

\section{Pengujian instrumen kuesioner}

\section{A. Pengujian validitas}

Uji validitas dilakukan dengan menggunakan korelasi bivariate antara skor masingmasing butir pertanyaan dengan dengan skore total. Dalam hal ini dapat dilihat pada analisis hasil output pada uji validitas (lihat lampiran), pada bagian item total statistik pada kolom corrected item-total correlation, merupakan nilai $\mathrm{r}$ hitung untuk masing-masing pertanyaan. Nilai $r$ tabel untuk jumlah responden (n) 53 dan tingkat signifikan ( $\alpha$ ) 5 persen telah menunjukkan bahwa seluruh variabel pertanyaan yaitu bukti fisik,kehandalan, tanggapan, jaminan dan perhatian yang tercantum di dalam kuesioner baik variabel importance dan performance dinyatakan valid, karena $r_{\text {hitung }}$ lebih besar dari $(>) r_{\text {tabel/kritis }}$ yaitu 0,344 . Dari hasil pengolahan data untuk seluruh variabel "importance" diperoleh $r_{\text {hitung }}(>) r_{\text {tabel/kritis, maka dapat }}$ disimpulkan seluruh variabel adalah valid. Untuk lebih jelasnya dapat dilihat pada Tabel .1.1.

Tabel 1

Hasil Uji Validitas Variabel Importance

\begin{tabular}{|l|c|c|c|c|}
\hline \multicolumn{1}{|c|}{ Variabel } & $\begin{array}{c}\text { Nilai Korelasi } \\
\mathbf{R}_{\text {hitung }}\end{array}$ & $\begin{array}{c}\text { Nilai } \\
\mathbf{R}_{\text {kritis/table }}\end{array}$ & Keterangan & Kesimpulan \\
\hline Importance_1 & 0,754 & 0,344 & $\mathrm{R}_{\text {hitung }}>\mathrm{R}_{\text {tabel/kritis }}$ & Valid \\
\hline Importance_2 & 0,792 & 0,344 & $\mathrm{R}_{\text {hitung }}>\mathrm{R}_{\text {tabel/kritis }}$ & Valid \\
\hline Importance_3 & 0,506 & 0,344 & $\mathrm{R}_{\text {hitung }}>\mathrm{R}_{\text {tabel/kritis }}$ & Valid \\
\hline Importance_4 & 0,791 & 0,344 & $\mathrm{R}_{\text {hitung }}>\mathrm{R}_{\text {tabel/kritis }}$ & Valid \\
\hline Importance_5 & 0,441 & 0,344 & $\mathrm{R}_{\text {hitung }}>\mathrm{R}_{\text {tabel/kritis }}$ & Valid \\
\hline Importance_6 & 0,510 & 0,344 & $\mathrm{R}_{\text {hitung }}>\mathrm{R}_{\text {tabel/kritis }}$ & Valid \\
\hline Importance_7 & 0,393 & 0,344 & $\mathrm{R}_{\text {hitung }}>\mathrm{R}_{\text {tabel/kritis }}$ & Valid \\
\hline Importance_8 & 0,515 & 0,344 & $\mathrm{R}_{\text {hitung }}>\mathrm{R}_{\text {tabel/kritis }}$ & Valid \\
\hline Importance_9 & 0,781 & 0,344 & $\mathrm{R}_{\text {hitung }}>\mathrm{R}_{\text {tabel/kritis }}$ & Valid \\
\hline Importance_10 & 0,754 & 0,344 & $\mathrm{R}_{\text {hitung }}>\mathrm{R}_{\text {tabel/kritis }}$ & Valid \\
\hline Importance_11 & 0,502 & 0,344 & $\mathrm{R}_{\text {hitung }}>\mathrm{R}_{\text {tabel/kritis }}$ & Valid \\
\hline Importance_12 & 0,625 & 0,344 & $\mathrm{R}_{\text {hitung }}>\mathrm{R}_{\text {tabel/kritis }}$ & Valid \\
\hline Importance_13 & 0,637 & 0,344 & $\mathrm{R}_{\text {hitung }}>\mathrm{R}_{\text {tabel/kritis }}$ & Valid \\
\hline Importance_14 & 0,600 & 0,344 & $\mathrm{R}_{\text {hitung }}>\mathrm{R}_{\text {tabel/kritis }}$ & Valid \\
\hline Importance_15 & 0,347 & 0,344 & $\mathrm{R}_{\text {hitung }}>\mathrm{R}_{\text {tabel/kritis }}$ & Valid \\
\hline Importance_16 & 0,867 & 0,344 & $\mathrm{R}_{\text {hitung }}>\mathrm{R}_{\text {tabel/kritis }}$ & Valid \\
\hline
\end{tabular}




\begin{tabular}{|l|c|c|c|c|}
\hline Importance_17 & 0,817 & 0,344 & $\mathrm{R}_{\text {hitung }}>\mathrm{R}_{\text {tabel/kritis }}$ & Valid \\
\hline Importance_18 & 0,620 & 0,344 & $\mathrm{R}_{\text {hitung }}>\mathrm{R}_{\text {tabel/kritis }}$ & Valid \\
\hline Importance_19 & 0,387 & 0,344 & $\mathrm{R}_{\text {hitung }}>\mathrm{R}_{\text {tabel/kritis }}$ & Valid \\
\hline Importance_20 & 0,471 & 0,344 & $\mathrm{R}_{\text {hitung }}>\mathrm{R}_{\text {tabel/kritis }}$ & Valid \\
\hline Importance_21 & 0,760 & 0,344 & $\mathrm{R}_{\text {hitung }}>\mathrm{R}_{\text {tabel/kritis }}$ & Valid \\
\hline Importance_22 & 0,701 & 0,344 & $\mathrm{R}_{\text {hitung }}>\mathrm{R}_{\text {tabel/kritis }}$ & Valid \\
\hline Importance_23 & 0,515 & 0,344 & $\mathrm{R}_{\text {hitung }}>\mathrm{R}_{\text {tabel/kritis }}$ & Valid \\
\hline Importance_24 & 0,798 & 0,344 & $\mathrm{R}_{\text {hitung }}>\mathrm{R}_{\text {tabel/kritis }}$ & Valid \\
\hline Importance_25 & 0,850 & 0,344 & $\mathrm{R}_{\text {hitung }}>\mathrm{R}_{\text {tabel/kritis }}$ & Valid \\
\hline Importance_26 & 0,578 & 0,344 & $\mathrm{R}_{\text {hitung }}>\mathrm{R}_{\text {tabel/kritis }}$ & Valid \\
\hline Importance_27 & 0,737 & 0,344 & $\mathrm{R}_{\text {hitung }}>\mathrm{R}_{\text {tabel/kritis }}$ & Valid \\
\hline Importance_28 & 0,783 & 0,344 & $\mathrm{R}_{\text {hitung }}>\mathrm{R}_{\text {tabel/kritis }}$ & Valid \\
\hline Importance_29 & 0,701 & 0,344 & $\mathrm{R}_{\text {hitung }}>\mathrm{R}_{\text {tabel/kritis }}$ & Valid \\
\hline Importance_30 & 0,853 & 0,344 & $\mathrm{R}_{\text {hitung }}>\mathrm{R}_{\text {tabel/kritis }}$ & Valid \\
\hline Importance_31 & 0,825 & 0,344 & $\mathrm{R}_{\text {hitung }}>\mathrm{R}_{\text {tabel/krits }}$ & Valid \\
\hline Importance_32 & 0,878 & 0,344 & $\mathrm{R}_{\text {hitung }}>\mathrm{R}_{\text {tabel/krits }}$ & Valid \\
\hline Importance_33 & 0,817 & 0,344 & $\mathrm{R}_{\text {hitung }}>\mathrm{R}_{\text {tabel/kritis }}$ & Valid \\
\hline
\end{tabular}

Sumber: Lampiran 4 (diolah)

Selanjutnya dari hasil pengolahan data untuk seluruh variabel "performance" diperoleh

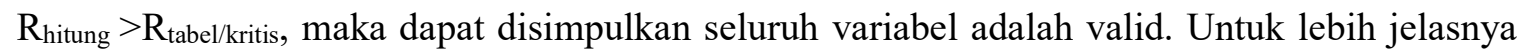
dapat dilihat pada Tabel 1.2

Tabel 2

Hasil Uji Validitas Variabel Performance

\begin{tabular}{|c|c|c|c|c|}
\hline Variabel & $\begin{array}{c}\text { Nilai Korelasi } \\
\text { R }_{\text {hitung }}\end{array}$ & $\begin{array}{c}\text { Nilai } \\
\mathbf{R}_{\text {kritis/table }}\end{array}$ & Keterangan & Kesimpulan \\
\hline Performance_1 & 0,819 & 0,344 & $\mathrm{R}_{\text {hitung }}>\mathrm{R}_{\text {tabel/kritis }}$ & Valid \\
\hline Performance_2 & 0,850 & 0,344 & $\mathrm{R}_{\text {hitung }}>\mathrm{R}_{\text {tabel/kritis }}$ & Valid \\
\hline Performance 3 & 0,671 & 0,344 & $\mathrm{R}_{\text {hitung }}>\mathrm{R}_{\text {tabel/kritis }}$ & Valid \\
\hline Performance_4 & 0,563 & 0,344 & $\mathrm{R}_{\text {hitung }}>\mathrm{R}_{\text {tabel/kritis }}$ & Valid \\
\hline Performance_5 & 0,186 & 0,344 & $\mathrm{R}_{\text {hitung }}>\mathrm{R}_{\text {tabel/kritis }}$ & Valid \\
\hline Performance_6 & 0,668 & 0,344 & $\mathrm{R}_{\text {hitung }}>\mathrm{R}_{\text {tabel/kritis }}$ & Valid \\
\hline Performance_7 & 0,150 & 0,344 & $\mathrm{R}_{\text {hitung }}>\mathrm{R}_{\text {tabel/kritis }}$ & Valid \\
\hline Performance_8 & 0,566 & 0,344 & $\mathrm{R}_{\text {hitung }}>\mathrm{R}_{\text {tabel/kritis }}$ & Valid \\
\hline Performance_9 & 0,802 & 0,344 & $\mathrm{R}_{\text {hitung }}>\mathrm{R}_{\text {tabel/kritis }}$ & Valid \\
\hline Performance_10 & 0,852 & 0,344 & $\mathrm{R}_{\text {hitung }}>\mathrm{R}_{\text {tabel/kritis }}$ & Valid \\
\hline Performance_11 & 0,831 & 0,344 & $\mathrm{R}_{\text {hitung }}>\mathrm{R}_{\text {tabel/kritis }}$ & Valid \\
\hline Performance_12 & 0,749 & 0,344 & $\mathrm{R}_{\text {hitung }}>\mathrm{R}_{\text {tabel } / \text { kritis }}$ & Valid \\
\hline Performance_13 & 0,940 & 0,344 & $\mathrm{R}_{\text {hitung }}>\mathrm{R}_{\text {tabel/kritis }}$ & Valid \\
\hline Performance_14 & 0,918 & 0,344 & $\mathrm{R}_{\text {hitung }}>\mathrm{R}_{\text {tabel/kritis }}$ & Valid \\
\hline Performance_15 & 0,670 & 0,344 & $\mathrm{R}_{\text {hitung }}>\mathrm{R}_{\text {tabel/kritis }}$ & Valid \\
\hline Performance_16 & 0,760 & 0,344 & $\mathrm{R}_{\text {hitung }}>\mathrm{R}_{\text {tabel/kritis }}$ & Valid \\
\hline Performance_17 & 0,650 & 0,344 & $\mathrm{R}_{\text {hitung }}>\mathrm{R}_{\text {tabel/kritis }}$ & Valid \\
\hline Performance_18 & 0,733 & 0,344 & $\mathrm{R}_{\text {hitung }}>\mathrm{R}_{\text {tabel/kritis }}$ & Valid \\
\hline Performance_19 & 0,623 & 0,344 & $\mathrm{R}_{\text {hitung }}>\mathrm{R}_{\text {tabel } / \text { kritis }}$ & Valid \\
\hline Performance_20 & 0,472 & 0,344 & $\mathrm{R}_{\text {hitung }}>\mathrm{R}_{\text {tabel/kritis }}$ & Valid \\
\hline Performance_21 & 0,653 & 0,344 & $\mathrm{R}_{\text {hitung }}>\mathrm{R}_{\text {tabel/kritis }}$ & Valid \\
\hline Performance_22 & 0,715 & 0,344 & $\mathrm{R}_{\text {hitung }}>\mathrm{R}_{\text {tabel/kritis }}$ & Valid \\
\hline Performance_23 & 0,502 & 0,344 & $\mathrm{R}_{\text {hitung }}>\mathrm{R}_{\text {tabel/kritis }}$ & Valid \\
\hline Performance_24 & 0,862 & 0,344 & $\mathrm{R}_{\text {hitung }}>\mathrm{R}_{\text {tabel/kritis }}$ & Valid \\
\hline
\end{tabular}




\begin{tabular}{|l|l|l|l|c|}
\hline Performance_25 & 0,891 & 0,344 & $\mathrm{R}_{\text {hitung }}>\mathrm{R}_{\text {tabel/kritis }}$ & Valid \\
\hline Performance_26 & 0,736 & 0,344 & $\mathrm{R}_{\text {hitung }}>\mathrm{R}_{\text {tabel } / \text { ritis }}$ & Valid \\
\hline Performance_27 & 0,657 & 0,344 & $\mathrm{R}_{\text {hitung }}>\mathrm{R}_{\text {tabel } / \text { ritis }}$ & Valid \\
\hline Performance_28 & 0,837 & 0,344 & $\mathrm{R}_{\text {hitung }}>\mathrm{R}_{\text {tabel } / \text { ritis }}$ & Valid \\
\hline Performance_29 & 0,780 & 0,344 & $\mathrm{R}_{\text {hitung }}>\mathrm{R}_{\text {tabel/kritis }}$ & Valid \\
\hline Performance_30 & 0,940 & 0,344 & $\mathrm{R}_{\text {hitung }}>\mathrm{R}_{\text {tabel/kritis }}$ & Valid \\
\hline Performance_31 & 0,889 & 0,344 & $\mathrm{R}_{\text {hitung }}>\mathrm{R}_{\text {tabel/kritis }}$ & Valid \\
\hline Performance_32 & 0,855 & 0,344 & $\mathrm{R}_{\text {hitung }}>\mathrm{R}_{\text {tabel/kritis }}$ & Valid \\
\hline Performance_33 & 0,573 & 0,344 & $\mathrm{R}_{\text {hitung }}>\mathrm{R}_{\text {tabel/kritis }}$ & Valid \\
\hline
\end{tabular}

Sumber: Lampiran 5 (diolah)

\section{B. Uji reliabilitas}

Intrumen yang digunakan dalam penelitian ini adalah berupa angket/kuesioner yang berisi pertanyaan atau pernyataan, maka reliabilitas instrumennya diuji dengan menggunakan rumus alpha dari Cronbach. Nunnaly (1967) mengatakan bahwa suatu kontruk atau variabel dikatakan reliabilitas jika memberikan nilai koefisien Cronbach alpha hitung $>0,60$ dan memenuhi syarat untuk digunakan sebagai alat pengukur analisis (lihat Ghozali, 2006: 42).

Berikut hasil perhitungan per-item variabel Uji Reliabilitas Kualitas Pelayanan Rumah Sakit seperti terlihat pada Tabel 1.3 berikut:

Tabel 3

Variabel Importance dan Uji Reliabilitas

\begin{tabular}{|l|c|c|c|}
\hline Variabel & $\begin{array}{c}\text { Cronbach's } \\
\text { Alpha of items }\end{array}$ & $\begin{array}{c}\text { Standar Pengukuran } \\
(>\mathbf{0 , 6 0})\end{array}$ & Keterangan \\
\hline Importance_1 & 0,961 & 0,60 & Reliabel/Konsisten \\
\hline Importance_2 & 0,961 & 0,60 & Reliabel/Konsisten \\
\hline Importance_3 & 0,962 & 0,60 & Reliabel/Konsisten \\
\hline Importance_4 & 0,960 & 0,60 & Reliabel/Konsisten \\
\hline Importance_5 & 0,962 & 0,60 & Reliabel/Konsisten \\
\hline Importance_6 & 0,962 & 0,60 & Reliabel/Konsisten \\
\hline Importance_7 & 0,963 & 0,60 & Reliabel/Konsisten \\
\hline Importance_8 & 0,962 & 0,60 & Reliabel/Konsisten \\
\hline Importance_9 & 0,961 & 0,60 & Reliabel/Konsisten \\
\hline Importance_10 & 0,961 & 0,60 & Reliabel/Konsisten \\
\hline Importance_11 & 0,962 & 0,60 & Reliabel/Konsisten \\
\hline Importance_12 & 0,962 & 0,60 & Reliabel/Konsisten \\
\hline Importance_13 & 0,962 & 0,60 & Reliabel/Konsisten \\
\hline Importance_14 & 0,962 & 0,60 & Reliabel/Konsisten \\
\hline Importance_15 & 0,963 & 0,60 & Reliabel/Konsisten \\
\hline Importance_16 & 0,960 & 0,60 & Reliabel/Konsisten \\
\hline Importance_17 & 0,960 & 0,60 & Reliabel/Konsisten \\
\hline Importance_18 & 0,962 & 0,60 & Reliabel/Konsisten \\
\hline Importance_19 & 0,963 & 0,60 & Reliabel/Konsisten \\
\hline Importance_20 & 0,962 & 0,60 & Reliabel/Konsisten \\
\hline Importance_21 & 0,961 & 0,60 & Reliabel/Konsisten \\
\hline Importance_22 & 0,961 & 0,60 & Reliabel/Konsisten \\
\hline Importance_23 & 0,962 & 0,60 & Reliabel/Konsisten \\
\hline Importance_24 & 0,960 & 0,60 & Konsisten \\
\hline
\end{tabular}




\begin{tabular}{|l|l|l|l|}
\hline Importance_25 & 0,960 & 0,60 & Reliabel/Konsisten \\
\hline Importance_26 & 0,962 & 0,60 & Reliabel/Konsisten \\
\hline Importance_27 & 0,961 & 0,60 & Reliabel/Konsisten \\
\hline Importance_28 & 0,961 & 0,60 & Reliabel/Konsisten \\
\hline Importance_29 & 0,961 & 0,60 & Reliabel/Konsisten \\
\hline Importance_30 & 0,960 & 0,60 & Reliabel/Konsisten \\
\hline Importance_31 & 0,960 & 0,60 & Reliabel/Konsisten \\
\hline Importance_32 & 0,960 & 0,60 & Reliabel/Konsisten \\
\hline Importance_33 & 0,960 & 0,60 & Reliabel/Konsisten \\
\hline
\end{tabular}

Sumber: Lampiran 6 (diolah)

Tabel 4

Variabel Performance dan Uji Reliabilitas

\begin{tabular}{|c|c|c|c|}
\hline Variabel & $\begin{array}{c}\text { Cronbach's } \\
\text { Alpha of items }\end{array}$ & $\begin{array}{c}\text { Standar Pengukuran } \\
(>0,60)\end{array}$ & Keterangan \\
\hline Performance_1 & 0,970 & 0,60 & Reliabel/Konsisten \\
\hline Performance_2 & 0,970 & 0,60 & Reliabel/Konsisten \\
\hline Performance_3 & 0,971 & 0,60 & Reliabel/Konsisten \\
\hline Performance_4 & 0,972 & 0,60 & Reliabel/Konsisten \\
\hline Performance 5 & 0,973 & 0,60 & Reliabel/Konsisten \\
\hline Performance_6 & 0,971 & 0,60 & Reliabel/Konsisten \\
\hline Performance_7 & 0,972 & 0,60 & Reliabel/Konsisten \\
\hline Performance_8 & 0,972 & 0,60 & Reliabel/Konsisten \\
\hline Performance_9 & 0,970 & 0,60 & Reliabel/Konsisten \\
\hline Performance_10 & 0,970 & 0,60 & Reliabel/Konsisten \\
\hline Performance_11 & 0,970 & 0,60 & Reliabel/Konsisten \\
\hline Performance_12 & 0,971 & 0,60 & Reliabel/Konsisten \\
\hline Performance 13 & 0,969 & 0,60 & Reliabel/Konsisten \\
\hline Performance_14 & 0,970 & 0,60 & Reliabel/Konsisten \\
\hline Performance_15 & 0,971 & 0,60 & Reliabel/Konsisten \\
\hline Performance_16 & 0,971 & 0,60 & Reliabel/Konsisten \\
\hline Performance 17 & 0,971 & 0,60 & Reliabel/Konsisten \\
\hline Performance_18 & 0,971 & 0,60 & Reliabel/Konsisten \\
\hline Performance_19 & 0,971 & 0,60 & Reliabel/Konsisten \\
\hline Performance_20 & 0,972 & 0,60 & Reliabel/Konsisten \\
\hline Performance_21 & 0,971 & 0,60 & Reliabel/Konsisten \\
\hline Performance_22 & 0,971 & 0,60 & Reliabel/Konsisten \\
\hline Performance_23 & 0,972 & 0,60 & Reliabel/Konsisten \\
\hline Performance_24 & 0,970 & 0,60 & Reliabel/Konsisten \\
\hline Performance_25 & 0,970 & 0,60 & Reliabel/Konsisten \\
\hline Performance_26 & 0,971 & 0,60 & Reliabel/Konsisten \\
\hline Performance_27 & 0,971 & 0,60 & Reliabel/Konsisten \\
\hline Performance_28 & 0,970 & 0,60 & Reliabel/Konsisten \\
\hline Performance_29 & 0,971 & 0,60 & Reliabel/Konsisten \\
\hline Performance_30 & 0,970 & 0,60 & Reliabel/Konsisten \\
\hline Performance_31 & 0,970 & 0,60 & Reliabel/Konsisten \\
\hline Performance_32 & 0,970 & 0,60 & Reliabel/Konsisten \\
\hline Performance 33 & 0,972 & 0,60 & Reliabel/Konsisten \\
\hline
\end{tabular}

Sumber: Lampiran 7 (diolah) 
Hasil uji realibilitas yang peneliti telah lakukan kepada 53 responden pada taraf standar perbandingan Cronbach's Alpha $>0,60$, telah menunjukkan bahwa seluruh variabel pertanyaan yaitu bukti fisik,kehandalan, tanggapan, jaminan dan perhatian yang tercantum di dalam kuesioner baik variabel importance dan performance dinyatakan realibel atau konsisten, karena nilai Cronbach's Alpha lebih besar dari (>)0,60. kesimpulannya adalah item-item tersebut reliabilitas. Hal ini membuktikan bahwa alat indikator variabel dari penilaian responden mengenai seberapa penting pelayanan non paramedis dan Pelayanan paramedis sebagai kunci keberhasilan pelayanan serta mengukur kinerja pelayanan rumah sakit terebut adalah reliabilitas. Berikut hasil perhitungan scala Total Reliabilitas Importance dan Performance dapat dilihat pada Tabel 1.5 berikut:

Tabel 5

Hasil Perhitungan Scala Total Realibilitas Importance dan Performance

\begin{tabular}{|c|c|c|c|c|}
\hline Variabel & $\begin{array}{c}\text { Cronbach's } \\
\text { Alpha }\end{array}$ & $\begin{array}{c}\text { Standar } \\
\text { Pengukuran }\end{array}$ & $\begin{array}{c}\text { N of items } \\
\text { Variabel }\end{array}$ & Keterangan \\
\hline Importance & 0,962 & 0,60 & 33 & Realibel atau Konsisten \\
\hline Performance & 0,972 & 0,60 & 33 & Realibel atau Konsisten \\
\hline
\end{tabular}

Sumber: Lampiran 8 (diolah)

\section{Analisis kuadran diagram IPA}

Pada penelitian ini peneliti menyebarkan kuesioner kepada responden, di mana masingmasing responden memberikan penilaian terhadap seberapa penting variabel-variabel penelitian terhadap keberhasilan pemeliharaan bangunan gedung milik Badan Tenaga Nuklir Serpong. Para responden juga memberikan penilaian terhadap kinerja terhadap kinerja pemeliharaan bangunan gedung kantor yang telah berlangsung di mana indikatornya didasarkan atas faktor-faktor kunci dalam menentukan keberhasilan pemeliharaan bangunan gedung, dinilai dari kinerja yang sangat tinggi sampai kinerja yang sangat rendah. Hasil penilaian responden terhadap arti penting (importance) daan tingkat kinerja (performance) adalah sebagai berikut:

Tabel 6

Hasil Penilaian Responden terhadap Variabel Penelitian

\begin{tabular}{|c|l|c|c|}
\hline No. & \multicolumn{1}{|c|}{ Variabel } & $\begin{array}{c}\text { Importance } \\
(\boldsymbol{X})\end{array}$ & $\begin{array}{c}\text { Performance } \\
(\text { Y })\end{array}$ \\
\hline 1 & Ruang Rawat inap tertata rapih dan bersih. & 3.6604 & 3.5472 \\
\hline 2 & Ruang rawat inap nyaman. & 3.7358 & 3.5849 \\
\hline 3 & Memiliki alat-alat medis yang cukup lengkap. & 3.9623 & 3.9057 \\
\hline 4 & Penampilan bersih dan rapi & 3.7170 & 3.6792 \\
\hline 5 & Penampilan perawat bersih dan rapi & 3.9811 & 3.9811 \\
\hline 6 & Kursi roda/ troli tersedia dikantor penerimaan untuk membawa pasien & 4.0189 & 3.9623 \\
\hline
\end{tabular}




\begin{tabular}{|c|c|c|c|}
\hline & keruang rawat inap. & & \\
\hline 7 & Tempat tidur telah dipersiapkan bersih, rapi dan siap pakai & 3.9623 & 3.9057 \\
\hline 8 & Alat makan dan minum bersih dan baik & 3.9811 & 3.9245 \\
\hline 9 & Prosedur ppenerimaan pasien dilayani secara cepat dan tidak berbelit. & 3.8302 & 3.6415 \\
\hline 10 & Dokter datang tepat waktu & 3.7925 & 3.6226 \\
\hline 11 & Kesiapan dokter melayani pasien & 3.8491 & 3.6981 \\
\hline 12 & Dokter bertindak cepat & 3.8868 & 3.8302 \\
\hline 13 & Kesiapan perawat melayani pasien setiap saat & 3.8302 & 3.6226 \\
\hline 14 & $\begin{array}{l}\text { Perawat melaporkan segala detail perubahan pasien kepada dokter } \\
\text { sewaktu melakukan kunjungan }\end{array}$ & 3.9057 & 3.7547 \\
\hline 15 & Perawat selalu memberi obat pasien sesuai prosedur pemberian obat & 3.9623 & 3.8868 \\
\hline 16 & $\begin{array}{l}\text { Perawat segera menghubungi dokter mengenai obat dan makanan } \\
\text { dokter }\end{array}$ & 3.8113 & 3.7925 \\
\hline 17 & Perawat memperhatikan keluhan keluarga pasien & 3.8113 & 3.7736 \\
\hline 18 & Dokter selalu menanyakan keluhan pasien & 3.9245 & 3.8302 \\
\hline 19 & Dokter memberikan kesempatan bertanya kepada pasien & 3.9245 & 3.8491 \\
\hline 20 & Dokter memberi penjelasan mengenai penyakit & 3.9245 & 3.9057 \\
\hline 21 & Perawat bersikap ramah dan sopan & 3.6981 & 3.6604 \\
\hline 22 & Perawat memperhatikan kebutuhan dan keluhan pasien & 3.8113 & 3.6981 \\
\hline 23 & Tersedia dokter spesialis & 3.9245 & 3.8679 \\
\hline 24 & Prilaku menimbulkan rasa aman & 3.8113 & 3.7547 \\
\hline 25 & Perawat terdidik dan mampu melayani pasien & 3.8113 & 3.7547 \\
\hline 26 & Biaya perawatan terjangkau & 3.9434 & 3.7736 \\
\hline 27 & Menjaga kerahasiaan pasien selama dalam ruang inap & 3.9245 & 3.8868 \\
\hline 28 & Memberi jaminan akan kesembuhan pasien & 3.7358 & 3.6415 \\
\hline 29 & $\begin{array}{l}\text { Dokter berusaha menenangkan rasa cemas pasien terhadap penyakit } \\
\text { yang diderita }\end{array}$ & 3.9057 & 3.7925 \\
\hline 30 & $\begin{array}{l}\text { Perawat meluangkan waktu khusus untuk berkomunikasi dengan } \\
\text { pasien }\end{array}$ & 3.7736 & 3.6415 \\
\hline 31 & $\begin{array}{l}\text { Perawat selalu mengingatkan keamanan akan menyimpan barang } \\
\text { berharga pasien dan keluarganya }\end{array}$ & 3.7358 & 3.6226 \\
\hline 32 & Waktu untuk berkonsultasi keluarga pasien terpenuhi & 3.7736 & 3.6415 \\
\hline 33 & $\begin{array}{l}\text { Menghibur dan memberikan dorongan kepada pasien supaya cepat } \\
\text { sembuh dan mendoakan mereka }\end{array}$ & 3.7547 & 3.7170 \\
\hline & Rata-rata Hasil Penilaian & 3.85 & 3.76 \\
\hline
\end{tabular}

Sumber: Lampiran 9 (diolah)

Berdasarkan tingkat arti pentingnya, variabel-variabel penelitian dibagi menjadi dua bagian yaitu variabel yang menurut responden dinilai penting dan variabel yang menurut responden dinilai tidak penting. Batas kedua bagian tersebut adalah nilai rata-rata pada skala pengukuran tingkat arti penting yaitu tiga belas variabel yang nilai arti pentingnya lebih besar dari nilai rata-rata merupakan variabel yang dinilai penting. Variabel yang nilai arti pentingnya lebih kecil dari nilai rata-rata merupakan varibel yang dinilai kurang penting.

Hasil pengolahan data penilaian responden terhadap tingkat arti pentingnya (importance) variabel faktor-faktor keberhasilan pelayanan rumah sakit, berdasarkan urutan tingkat arti penting disajikan di Tabel 1.7 di bawah ini. 
Tabel .7

Hasil penilaian responden terhadap importance

\begin{tabular}{|c|c|c|c|c|c|}
\hline No & Variabel & Skor & Mean & $\begin{array}{l}\text { Persen } \\
(\%)\end{array}$ & Ket. \\
\hline 1 & Ruang Rawat inap tertata rapih dan bersih. & 193 & 3,66 & 73 & penting \\
\hline 2 & Ruang rawat inap nyaman. & 195 & 3,74 & 73 & penting \\
\hline 3 & Memiliki alat-alat medis yang cukup lengkap. & 207 & 3,96 & 78 & penting \\
\hline 4 & Penampilan bersih dan rapi & 198 & 3,72 & 75 & Penting \\
\hline 5 & Penampilan perawat bersih dan rapi & 211 & 3,98 & 80 & $\begin{array}{l}\text { Sangat } \\
\text { penting }\end{array}$ \\
\hline 6 & $\begin{array}{l}\text { Kursi roda/ troli tersedia dikantor penerimaan untuk membawa } \\
\text { pasien keruang rawat inap. }\end{array}$ & 210 & 3,02 & 79 & penting \\
\hline 7 & Tempat tidur telah dipersiapkan bersih, rapi dan siap pakai & 208 & 3,96 & 78 & penting \\
\hline 8 & Alat makan dan minum bersih dan baik & 209 & 3,98 & 79 & penting \\
\hline 9 & $\begin{array}{l}\text { Prosedur ppenerimaan pasien dilayani secara cepat dan tidak } \\
\text { berbelit. }\end{array}$ & 265 & 3,83 & 100 & $\begin{array}{l}\text { Sangat } \\
\text { Penting }\end{array}$ \\
\hline 10 & Dokter datang tepat waktu & 265 & 3,79 & 100 & $\begin{array}{l}\text { Sangat } \\
\text { Penting }\end{array}$ \\
\hline 11 & Kesiapan dokter melayani pasien & 265 & 3,85 & 100 & $\begin{array}{l}\text { Sangat } \\
\text { penting }\end{array}$ \\
\hline 12 & Dokter bertindak cepat & 265 & 3,89 & 100 & $\begin{array}{l}\text { Sangat } \\
\text { Penting }\end{array}$ \\
\hline 13 & Kesiapan perawat melayani pasien setiap saat & 265 & 3,83 & 100 & $\begin{array}{l}\text { Sangat } \\
\text { Penting }\end{array}$ \\
\hline 14 & $\begin{array}{l}\text { Perawat melaporkan segala detail perubahan pasien kepada } \\
\text { dokter sewaktu melakukan kunjungan }\end{array}$ & 265 & 3,91 & 100 & $\begin{array}{l}\text { Sangat } \\
\text { Penting }\end{array}$ \\
\hline 15 & $\begin{array}{l}\text { Perawat selalu memberi obat pasien sesuai prosedur pemberian } \\
\text { obat }\end{array}$ & 265 & 3,96 & 100 & $\begin{array}{l}\text { Sangat } \\
\text { penting }\end{array}$ \\
\hline 16 & $\begin{array}{l}\text { Perawat segera menghubungi dokter mengenai obat dan } \\
\text { makanan dokter }\end{array}$ & 265 & 3,81 & 100 & $\begin{array}{l}\text { Sangat } \\
\text { penting }\end{array}$ \\
\hline 17 & Perawat memperhatikan keluhan keluarga pasien & 265 & 3,81 & 100 & $\begin{array}{l}\text { Sangat } \\
\text { penting }\end{array}$ \\
\hline 18 & Dokter selalu menanyakan keluhan pasien & 207 & 3,92 & 78 & penting \\
\hline 19 & Dokter memberikan kesempatan bertanya kepada pasien & 208 & 3,92 & 78 & penting \\
\hline 20 & Dokter memberi penjelasan mengenai penyakit & 209 & 3,92 & 79 & $\begin{array}{l}\text { Sangat } \\
\text { Penting }\end{array}$ \\
\hline 21 & Perawat bersikap ramah dan sopan & 203 & 3,70 & 77 & $\begin{array}{l}\text { Sangat } \\
\text { penting }\end{array}$ \\
\hline 22 & Perawat memperhatikan kebutuhan dan keluhan pasien & 206 & 3,81 & 78 & $\begin{array}{l}\text { Sangat } \\
\text { penting }\end{array}$ \\
\hline 23 & Tersedia dokter spesialis & 265 & 3.92 & 100 & $\begin{array}{l}\text { sangat } \\
\text { penting }\end{array}$ \\
\hline 24 & Prilaku menimbulkan rasa aman & 265 & 3,81 & 100 & $\begin{array}{l}\text { Sangat } \\
\text { sangat } \\
\text { penting }\end{array}$ \\
\hline 25 & Perawat terdidik dan mampu melayani pasien & 265 & 3,81 & 100 & $\begin{array}{l}\text { sangat } \\
\text { penting }\end{array}$ \\
\hline 26 & Biaya perawatan terjangkau & 265 & 3,94 & 100 & $\begin{array}{c}\text { sangat } \\
\text { penting }\end{array}$ \\
\hline 27 & Menjaga kerahasiaan pasien selama dalam ruang inap & 265 & 3,92 & 100 & $\begin{array}{l}\text { sangat } \\
\text { penting }\end{array}$ \\
\hline 28 & Memberi jaminan akan kesembuhan pasien & 265 & 3,74 & 100 & $\begin{array}{l}\text { sangat } \\
\text { penting }\end{array}$ \\
\hline 29 & $\begin{array}{l}\text { Dokter berusaha menenangkan rasa cemas pasien terhadap } \\
\text { penyakit yang diderita }\end{array}$ & 212 & 3,91 & 80 & $\begin{array}{l}\text { Sangat } \\
\text { penting }\end{array}$ \\
\hline 30 & $\begin{array}{l}\text { Perawat meluangkan waktu khusus untuk berkomunikasi } \\
\text { dengan pasien }\end{array}$ & 212 & 3,77 & 80 & $\begin{array}{l}\text { Sangat } \\
\text { penting }\end{array}$ \\
\hline
\end{tabular}




\begin{tabular}{|l|l|l|l|l|l|}
\hline 31 & $\begin{array}{l}\text { Perawat selalu mengingatkan keamanan akan menyimpan } \\
\text { barang berharga pasien dan keluarganya }\end{array}$ & 212 & 3,74 & 80 & $\begin{array}{l}\text { Sangat } \\
\text { penting }\end{array}$ \\
\hline 32 & Waktu untuk berkonsultasi keluarga pasien terpenuhi & 212 & 3,77 & 80 & $\begin{array}{l}\text { Sangat } \\
\text { penting }\end{array}$ \\
\hline 33 & $\begin{array}{l}\text { Menghibur dan memberikan dorongan kepada pasien supaya } \\
\text { cepat sembuh dan mendoakan mereka }\end{array}$ & 212 & 3,75 & 80 & $\begin{array}{l}\text { Sangat } \\
\text { penting }\end{array}$ \\
\hline & Rata-rata hasil penilaiaan & \multicolumn{3}{|l|}{4,29} & \\
\hline
\end{tabular}

Sumber: Lampiran 9 (diolah)

Dari Tabel 5.1.7 dapat disimpulkan bahwa seluruh variabel dinilai mempunyai arti penting yang tinggi oleh responden. Faktor yang menjadi keberhasilan dalam kualitas pelayanan rumah sakit yang dinilai paling tinggi arti pentingnya adalah faktor keberhasilan Keberadaan standar operasional prosedur (SOP) dengan skor 263 dan nilai rata-rata 4,29. Faktor keberhasilan dalam kualitas pelayanan yang dinilai dibawah rata-rata atau paling rendah adalah faktor keberhasilan keberadaan Ruang Rawat inap tertata rapih dan bersih.skor 193.

Selanjutnya untuk melihat dari tingkat kinerjanya dalam pelayanan rumah sakit variabel-variabel penelitian dibagi menjadi dua bagian yaitu variabel yang menurut responden dinilai kinerjanya paling tinggi dan kinerja yang dinilai rendah. Berikut hasil pengolahan data penilaian responden terhadap tingkat kinerja (Performance) variabel faktor keberhasilan dalam kualitas pelayanan, berdasarkan urutan tingkat kinerjanya disajikan dalam Tabel 1.8.

Tabel 8

Hasil Penilaian Responden Terhadap Performance

\begin{tabular}{|c|l|c|c|c|c|}
\hline No & \multicolumn{1}{|c|}{ Variabel } & Skor & Performance & $\begin{array}{c}\text { Persen } \\
(\%)\end{array}$ & Ket \\
\hline 1 & Ruang Rawat inap tertata rapih dan bersih. & 188 & 3,55 & 71 & Baik \\
\hline 2 & Ruang rawat inap nyaman. & 190 & 3,58 & 72 & Baik \\
\hline 3 & Memiliki alat-alat medis yang cukup lengkap. & 207 & 3,91 & 78 & Sangat Baik \\
\hline 4 & Penampilan bersih dan rapi & 195 & 3,68 & 73 & Baik \\
\hline 5 & Penampilan perawat bersih dan rapi & 211 & 3,98 & 80 & Sangat baik \\
\hline 6 & $\begin{array}{l}\text { Kursi roda/ troli tersedia dikantor penerimaan untuk } \\
\text { membawa pasien keruang rawat inap. }\end{array}$ & 210 & 3,96 & 79 & Sangat Baik \\
\hline 7 & Tempat tidur telah dipersiapkan bersih, rapi dan siap pakai & 207 & 3,91 & 78 & Sangat Baik \\
\hline 8 & Alat makan dan minum bersih dan baik & 208 & 3,92 & 78 & Sangat Baik \\
\hline 9 & $\begin{array}{l}\text { Prosedur ppenerimaan pasien dilayani secara cepat dan tidak } \\
\text { berbelit. }\end{array}$ & 193 & 3,64 & 72 & Baik \\
\hline 10 & Dokter datang tepat waktu & 192 & 3,62 & 72 & Baik \\
\hline 11 & Kesiapan dokter melayani pasien & 196 & 3,70 & 74 & Baik \\
\hline 12 & Dokter bertindak cepat & 203 & 3,83 & 77 & sangatBaik \\
\hline 13 & Kesiapan perawat melayani pasien setiap saat & 192 & 3,62 & 72 & Baik \\
\hline 14 & $\begin{array}{l}\text { Perawat melaporkan segala detail perubahan pasien kepada } \\
\text { dokter sewaktu melakukan kunjungan }\end{array}$ & 199 & 3,75 & 75 & Baik \\
\hline 15 & $\begin{array}{l}\text { Perawat selalu memberi obat pasien sesuai prosedur } \\
\text { pemberian obat }\end{array}$ & 206 & 3,89 & 78 & Sangat Baik \\
\hline 16 & $\begin{array}{l}\text { Perawat segera menghubungi dokter mengenai obat dan } \\
\text { makanan dokter }\end{array}$ & 201 & 3,79 & 76 & Baik \\
\hline 17 & Perawat memperhatikan keluhan keluarga pasien & 200 & 3,77 & 75 & Baik \\
\hline
\end{tabular}




\begin{tabular}{|c|l|c|c|c|c|}
\hline 18 & Dokter selalu menanyakan keluhan pasien & 203 & 3,83 & 77 & Sangat Baik \\
\hline 19 & Dokter memberikan kesempatan bertanya kepada pasien & 204 & 3,85 & 77 & Sangat Baik \\
\hline 20 & Dokter memberi penjelasan mengenai penyakit & 207 & 3,91 & 78 & Sangat Baik \\
\hline 21 & Perawat bersikap ramah dan sopan & 194 & 3,66 & 73 & Baik \\
\hline 22 & Perawat memperhatikan kebutuhan dan keluhan pasien & 196 & 3,70 & 74 & Baik \\
\hline 23 & Tersedia dokter spesialis & 205 & 3,87 & 77 & Sangat Baik \\
\hline 24 & Prilaku menimbulkan rasa aman & 199 & 3,75 & 75 & Baik \\
\hline 25 & Perawat terdidik dan mampu melayani pasien & 199 & 3,75 & 75 & Baik \\
\hline 26 & Biaya perawatan terjangkau & 200 & 3.77 & 75 & Baik \\
\hline 27 & Menjaga kerahasiaan pasien selama dalam ruang inap & 206 & 3,89 & 78 & SangatBaik \\
\hline 28 & Memberi jaminan akan kesembuhan pasien & 193 & 3,64 & 73 & Baik \\
\hline 29 & $\begin{array}{l}\text { Dokter berusaha menenangkan rasa cemas pasien terhadap } \\
\text { penyakit yang diderita }\end{array}$ & 200 & 3,79 & 75 & Baik \\
\hline 30 & $\begin{array}{l}\text { Perawat meluangkan waktu khusus untuk berkomunikasi } \\
\text { dengan pasien }\end{array}$ & 193 & 3,64 & 73 & Baik \\
\hline 31 & $\begin{array}{l}\text { Perawat selalu mengingatkan keamanan akan menyimpan } \\
\text { barang berharga pasien dan keluarganya }\end{array}$ & 192 & 3,62 & 72 & Baik \\
\hline 32 & Waktu untuk berkonsultasi keluarga pasien terpenuhi & 193 & 3,64 & 73 & Baik \\
\hline 33 & $\begin{array}{l}\text { Menghibur dan memberikan dorongan kepada pasien supaya } \\
\text { cepat sembuh dan mendoakan mereka }\end{array}$ & 197 & 3,72 & $\mathbf{3 , 7 7}$ & Baik \\
\hline & $\begin{array}{l}\mid 2 \\
\text { Rata-rata hasil penilaian }\end{array}$ & & \\
\hline
\end{tabular}

Sumber: Lampiran 10 (diolah)

Dari Tabel diatas dapat disimpulkan bahwa dua belas variabel (46,81 persen) dinilai telah mempunyai tingkat kinerja tinggi oleh responden dan dua puluh satu variabel $(69,99$ persen) dinilai tingkat kinerjanya rendah. Faktor yang menjadi keberhasilan dalam kualitas pelayanan yang dinilai paling tinggi tingkat kinerjanya adalah faktor keberhasilan Keberadaan standar operasional prosedur (SOP) dengan nilai 3,77. Faktor keberhasilan dalam pelayanan rumah sakit yang dinilai dibawah rata-rata atau paling rendah tingkat kinerjanya adalah faktor Ruang Rawat inap tertata rapih dan bersih dengan nilai 3,55. Selanjutnya untuk analisis kuadran, perhitungan hasil penilaian responden terhadap Importance dan Performance kualitas pelayanan ditampilkan dalam grafik Importance Performance Analysis. Hasil penilaian responden pada Tabel 5.16. Selanjutnya akan ditampilkan dalam dua macam grafik IPA. Grafik yang pertama menggunakan nilai rata-rata pada skala pengukuran tingkat Importance dan Performance sebagai garis pemisah antar kuadran seperti terlihat pada Gambar 1.1 berikut. 


\section{Gambar 1}

Hasil Penilaian Responden Terhadap Performance

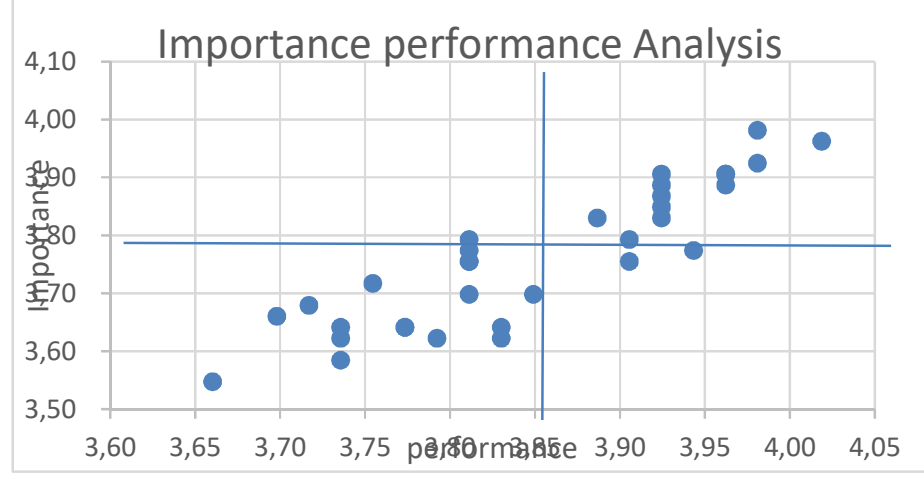

Berdasarkan Gambar 1.1 kualitas pelayanan Rumah sakit Raden Mataher dapat dikelompokkan dalam masing-masing kuadran sebagai berikut.

\section{Kuadran 1:}

\section{Tingkatkan kinerja (Concentrate here)}

Variabel 16 Perawat segera menghubungi dokter mengenai obat dan makanan PasienVariabel 17 Perawat memperhatikan keluhan keluarga pasien.

Kualitas pelayanan terletak pada Kuadran I dilaksanakannya pelayanan oleh Perawat segera menghubungi dokter mengenai obat dan makanan Pasien serta perawat memastikan keluhan keluarga pasien dianggap penting tetapi kenyataannya kinerjanya belum sesuai seperti yang diharapakan. Penilaian kondisi pelayanan yang belum sesuai seperti yang diharapkan pasien, dalam rangka menjaga kondisi kehandalan dalam pelayanan agar tetap berfungsi sebagaimana mestinya. Variabel yang masuk dalam kuadran ini harus ditingkatkan tindakan kontruktif yang terkosentrasi sehingga dapat membuahkan hasil yang maksimal.

\section{Kuadran II :}

Pertahankan kinerja (Keep up the good)

Variabel 5 Penampilan perawat bersih dan rapi

Variabel 6 Kursi roda/ troli tersedia dikantor penerimaan untuk membawa pasien keruang rawat inap.

Variabel 7 Tempat tidur telah dipersiapkan bersih, rapi dan siap pakai

Variabel 8 Alat makan dan minum bersih dan baik

Variabel 9 Prosedur ppenerimaan pasien dilayani secara cepat dan tidak berbelit.

Variabel 10 Dokter datang tepat waktu

Variabel 11 Kesiapan dokter melayani pasien

Variabel 12 Dokter bertindak cepat 
Variabel 13 Kesiapan perawat melayani pasien setiap saat

Variabel 14 Perawat melaporkan segala detail perubahan pasien kepada dokter sewaktu melakukan kunjungan

Variabel 15 Perawat selalu memberi obat pasien sesuai prosedur pemberian obat

Variabel 16 Perawat segera menghubungi dokter mengenai obat dan makanan dokter

Variabel 17 Perawat memperhatikan keluhan keluarga pasien

Variabel 18 Dokter selalu menanyakan keluhan pasien

Variabel 19 Dokter memberikan kesempatan bertanya kepada pasien

Variabel 20 Dokter memberi penjelasan mengenai penyakit

Variabel 21 Perawat bersikap ramah dan sopan

Variabel 22 Perawat memperhatikan kebutuhan dan keluhan pasien

Variabel 23 Tersedia dokter spesialis

Variabel 24 Prilaku menimbulkan rasa aman

Variabel 25 Perawat terdidik dan mampu melayani pasien

Variabel 26 Biaya perawatan terjangkau

Variabel 27 Menjaga kerahasiaan pasien selama dalam ruang inap

Variabel 28 Memberi jaminan akan kesembuhan pasien

Variabel 29 Dokter berusaha menenangkan rasa cemas pasien terhadap penyakit yang diderita

Variabel yang terletak pada kuadran II (dua) dinilai sebagai faktor keberhasilan pelayanan rumah sakit yang dinilai oleh responden memiliki arti penting dan kinerja tinggi dalam rangka menjaga kualitas pelayanan agar tetap memiliki tingkat kepuasan yang maksimal. Variabel-variabel yang termasuk dalam kuadran ini harus tetap dipertahankan kikinerja nya yang telah dicapai. Adapun kualitas pelayanan sebagai berikut:

Faktor Tangibility (Bukti fisik) dalam kualitas pelayanan rumah sakit seperti Penampilan perawat bersih dan rapi. Kursi roda/ troli tersedia dikantor penerimaan untuk membawa pasien keruang rawat inap. Tempat tidur telah dipersiapkan bersih, rapi dan siap pakai dan Alat makan dan minum bersih dan baik memiliki dianggap penting dan kinerjanya sesuai yang diharapkan/cukup baik.

Faktor Reliability (Handal) dalam kualitas pelayanan rumah sakit seperti: Dokter bertindak cepat dan Perawat selalu memberi obat pasien sesuai prosedur pemberian obat memiliki arti penting dan kinerja yansangat baik demi tingkat kepuasan pasien. 
Faktor Responsiveness ( Tanggap ) yang dilakukan oleh pihak rumah sakit dalam kualitas pelayanan seperti: Dokter selalu menanyakan keluhan pasien, Dokter memberikan kesempatan bertanya kepada pasien, Dokter memberi penjelasan mengenai penyakit memiliki arti pentin dan kualitas pelayanan rumah sakit agar tingkat kepuasan pasien semakin bertambah

Faktor Assurance (Jaminan) Tersedia dokter spesialis, Biaya perawatan terjangkau dan Menjaga kerahasiaan pasien selama dalam ruang inap dalam variabel tersebut memiliki tingkat kinerja yang sangat baik dalam meningkatkan kualitas pelayanan rumah sakit. Dengan adanya jaminan akan memberikan kepuasan pasien yang maksimal.

Berkaitan dengan Empaty ( Perhatian ) harus memberikan sikap empaty kepada pasien seperti: dokter berusaha menenangkan rasa cemas pasien terhadap penyakit yang diderita memang sangat penting dalam mendukung psikologi pasien sehingga pasien tidak memiliki tingkat kecemasan/stress dalam tindakan pengobatan.

\section{Kuadran III: Prioritas rendah (Low Priority)}

Variabel 1 Ruang Rawat inap tertata rapih dan bersih.

Variabel 2 Ruang rawat inap nyaman.

Variabel 4 Penampilan bersih dan rapi

Variabel 9 Prosedur penerimaan pasien dilayani secara cepat dan tidak berbelit.

Variabel 10 Dokter datang tepat waktu

Variabel 11 Kesiapan dokter melayani pasien

Variabel 13 Kesiapan perawat melayani pasien setiap saat

Variabel 21 Perawat bersikap ramah dan sopan

Variabel 22 Perawat memperhatikan kebutuhan dan keluhan pasien

Variabel 24 Prilaku menimbulkan rasa aman

Variabel 25 Perawat terdidik dan mampu melayani pasien

Variabel 28 Memberi jaminan akan kesembuhan pasien

Variabel 30 Perawat meluangkan waktu khusus untuk berkomunikasi dengan pasien

Variabel 31 Perawat selalu mengingatkan keamanan akan menyimpan barang berharga pasien dan keluarganya

Variabel 32 Waktu untuk berkonsultasi keluarga pasien terpenuhi 
Variabel 33 Menghibur dan memberikan dorongan kepada pasien supaya cepat sembuh dan mendoakan mereka

Variabel yang terletak pada kuadran III dinilai oleh responden memiliki arti penting yang sangat tinggi tetapi memiliki hasil kinerja sangat rendah, yang artinya setiap hasil responden dalam tiap variabel-variabel tersebut memiliki hasil kinerja sangat rendah. Dengan demikian pihak pengelola perlu memberikan perhatian terhadap faktor-faktor tesebut sehingga dalam keberadaan Tangibility, Reliability, Responsiveness, Assurance, Empaty untuk dapat ditingkatkan kinerjanya sesuai dengan perkembangan kebutuhan masing-masing pihak dengan tujuan kualitas pelayanan rumah sakit.

\section{Kuadran IV :}

\section{Cenderung berlebihan (Possible overkill)}

Variabel 14 Perawat melaporkan segala detail perubahan pasien kepada dokter sewaktu melakukan kunjungan

Kualitas pelayanan terletak pada Kuadran IV dilaksanakannya pelayanan oleh Perawat melaporkan segala detail perubahan pasien kepada dokter sewaktu melakukan kunjungan Penilaian kondisi pelayanan kinerjanya cukup baik namun dipandang cenderung berlebihan karna tidak diimbangi oleh variabel di kuadran III.

\section{KESIMPULAN}

Berdasarkan hasil analisis data dan pembahasan penelitian tentang Tingkat Kepuasan Masyarakat Terhadap Kinerja Pelayanan Rumah Sakit Raden Mattaher Jambi dapat disimpulkan hal-hal di bawah ini.

1. Hasil analisis Importance Performance Analysis dapat diidentifikasikan tingkat arti penting dan kinerja pelayanan Rumah sakit umum raden mattaher jambi. Faktor-faktor keberhasilan Pelayanan rumah sakit umum raden mattaher jambi dapat dikelompokkan dalam kuadran diagram IPA sebagai berikut.

a. Kuadran I: Konsentrasi disini/tingkatkan kinerja (Concentrate here)

Kualitas pelayanan terletak pada Kuadran I dilaksanakannya pelayanan oleh Perawat segera menghubungi dokter mengenai obat dan makanan Pasien serta perawat memastikan keluhan keluarga pasien dianggap penting tetatpi kenyataannya kinerjanya belum sesuai seperti yang diharpakan yang dinilai responden memiliki arti penting dan kinerja rendah dalam menjaga kualitas pelayanan rumah sakit. 
b. Kuadran II: Pertahankan kinerja (Keep up the good).

Faktor-faktor yang terletak pada kuadran 2 ini dinilai responden memiliki arti penting dan kinerja sangat tinggi dalam menjaga kualitas pelayanan rumah sakit.

Variabel 5 Penampilan perawat bersih dan rapi

Variabel 6 Kursi roda/ troli tersedia dikantor penerimaan untuk membawa pasien keruang rawat inap.

Variabel 7 Tempat tidur telah dipersiapkan bersih, rapi dan siap pakai

Variabel 8 Alat makan dan minum bersih dan baik

Variabel 9 Prosedur ppenerimaan pasien dilayani secara cepat dan tidak berbelit.

Variabel 10 Dokter datang tepat waktu

Variabel 11 Kesiapan dokter melayani pasien

Variabel 12 Dokter bertindak cepat

Variabel 13 Kesiapan perawat melayani pasien setiap saat

Variabel 14 Perawat melaporkan segala detail perubahan pasien kepada dokter sewaktu melakukan kunjungan

Variabel 15 Perawat selalu memberi obat pasien sesuai prosedur pemberian obat

Variabel 16 Perawat segera menghubungi dokter mengenai obat dan makanan dokter

Variabel 17 Perawat memperhatikan keluhan keluarga pasien

Variabel 18 Dokter selalu menanyakan keluhan pasien

Variabel 19 Dokter memberikan kesempatan bertanya kepada pasien

Variabel 20 Dokter memberi penjelasan mengenai penyakit

Variabel 21 Perawat bersikap ramah dan sopan

Variabel 22 Perawat memperhatikan kebutuhan dan keluhan pasien

Variabel 23 Tersedia dokter spesialis

Variabel 24 Prilaku menimbulkan rasa aman

Variabel 25 Perawat terdidik dan mampu melayani pasien

Variabel 26 Biaya perawatan terjangkau

Variabel 27 Menjaga kerahasiaan pasien selama dalam ruang inap

Variabel 28 Memberi jaminan akan kesembuhan pasien

Variabel 29 Dokter berusaha menenangkan rasa cemas pasien terhadap penyakit yang diderita 
c. Kuadran III: Prioritas rendah (Low Priority).

Variabel 1 Ruang Rawat inap tertata rapih dan bersih.

Variabel 2 Ruang rawat inap nyaman.

Variabel 4 Penampilan bersih dan rapi

Variabel 9 Prosedur penerimaan pasien dilayani secara cepat dan tidak berbelit.

Variabel 10 Dokter datang tepat waktu

Variabel 11 Kesiapan dokter melayani pasien

Variabel 13 Kesiapan perawat melayani pasien setiap saat

Variabel 21 Perawat bersikap ramah dan sopan

Variabel 22 Perawat memperhatikan kebutuhan dan keluhan pasien

Variabel 24 Prilaku menimbulkan rasa aman

Variabel 25 Perawat terdidik dan mampu melayani pasien

Variabel 28 Memberi jaminan akan kesembuhan pasien

Variabel 30 Perawat meluangkan waktu khusus untuk berkomunikasi dengan pasien

Variabel 31 Perawat selalu mengingatkan keamanan akan menyimpan barang berharga pasien dan keluarganya

Variabel 32 Waktu untuk berkonsultasi keluarga pasien terpenuhi

Variabel 33 Menghibur dan memberikan dorongan kepada pasien supaya cepat sembuh dan mendoakan mereka

Variabel yang terletak pada kuadran III dinilai oleh responden memiliki arti penting yang sangat tinggi tetapi memiliki hasil kinerja sangat rendah, yang artinya setiap hasil responden dalam tiap variabel-variabel tersebut memiliki hasil kinerja sangat rendah. Dengan demikian pihak pengelola perlu memberikan perhatian terhadap faktor-faktor tesebut sehingga dalam keberadaan Tangibility, Reliability, Responsiveness, Assurance, Empaty untuk dapat ditingkatkan kinerjanya sesuai dengan perkembangan kebutuhan masing-masing pihak dengan tujuan kualitas pelayanan rumah sakit.

d. Kuadran IV : Cenderung berlebihan (Possible overkill.)

Variabel 14 Perawat melaporkan segala detail perubahan pasien kepada dokter sewaktu melakukan kunjungan

Kualitas pelayanan terletak pada Kuadran IV dilaksanakannya pelayanan oleh Perawat melaporkan segala detail perubahan pasien kepada dokter sewaktu melakukan kunjungan Penilaian kondisi pelayanan kinerjanya cukup baik namun dipandang cenderung berlebihan. 


\section{DAFTAR PUSTAKA}

Anderson, R. Joanna K, dkk. 2009. Equity in Health Service, Emperical Analysis in Social Policy. Mass Ballinger Publishing Campany. Cambrige.

Arikunto, S. 199. Prosedur Penelitian Suatu Pendekatan Praktek, Rineka Cipta, Jakarta.

Assauri, S. 2003. Customer Service yang Baik Landasan Pencapaian Customer Satisfaction dalam Usahawan, No. 01, Tahun XXXII, Januari, hal.25-30: Jakarta.

Aviliani dan Wilfidrus, 1997. “Membangun Kepuasan Pelanggan Melalui Kualitas Pelayanan”. Usahawan No.05 Tahun XXVI, Mei.

Azwar, S. 1996. Reliabilitas dan Validitas. Edisi ketiga. Pustaka Pelajar, Yogyakarta.

Azwar, Azrul H. 1996. Menjaga Mutu Pelayanan Kesehatan. Jakarta: Pustaka Sinar Harapan.

Azis Slamet Wiyono dan M. Wahyuddin. (2005). Studi Tentang Kualitas Pelayanan dan Kepuasan Konsumen di Rumah Sakit Islam Manisrenggo Klaten, Surakarta: Program Pascasarjana Universitas Muhammadiyah Surakarta.

Budiyanto, FX. 1991. Pelayanan Pelanggan yang Bermutu, Seni Melakukan Pelanggan Sebagai Tamu. Jakarta: Binarupa Aksara.

Djarwanto Ps dan Pangestu Subagyo. 1999. Statistik Induktif. BPFE, Yogyakarta. Donabedian, A. 2000. Exprolation in Quality Assesment and Monitoring. Arbor Michigan: Health Administration Press. 